\title{
Non-governmental organization's contribution to women small-scale farmers: A case study of Tchenzema ward, Morogoro, Tanzania
}

\section{Kontribusi organisasi non-pemerintah untuk perempuan petani skala kecil: Studi kasus di daerah Tchenzema, Morogoro, Tanzania}

\author{
Emmanuel Michael Massay ${ }^{1,2 \bowtie}$ \& Majio Moshi Mujaya ${ }^{3,4}$ \\ ${ }^{1}$ Department of Sociology, Faculty of Social and Political Sciences, Universitas Airlangga, \\ Surabaya, 60286, East Java Province, Indonesia \\ ${ }^{2}$ Department of Gender Studies, The Mwalimu Nyerere Memorial Academy \\ Dar es Salaam, 9193, Tanzania \\ ${ }^{3}$ Department of Management, Faculty of Economic and Business, \\ Universitas Muhammadiyah Malang \\ Malang, 65144, East Java Province, Indonesia \\ ${ }^{4}$ Department of Social Studies, The Mwalimu Nyerere Memorial Academy \\ Dar es Salaam, 9193, Tanzania \\ E-mail of corresponding author: emanuelmichael81@gmail.com
}

\begin{abstract}
Tanzanian women play a vital role in the country's development and industrialization. Tanzania's agriculture is considered the country's backbone, but women are the driving force behind small-scale farming. This study aims to identify the types of NGOs that support women, small-scale farmers, to investigate the effects of NGOs, and the challenges that small-scale farmers face in Tchenzema ward. The transition and growth model development theory, and patriarchy theory, were used in the study. The study revealed that poor transportation, crop illnesses and insects, lack of pesticides, price fluctuation, lack of energy, and high agricultural equipment prices are some of the issues faced by women small-scale farmers in Tchenzema ward. This study concludes that the lack of collaboration between the Tanzanian government and farmers causes farmers to only rely on NGOs. The government and nongovernmental organizations need to support women small-scale farmers so as to solve the challenges, and raising the output, hence let the agriculture sector achieves its national aim of economic growth.
\end{abstract}

Keywords: agriculture; non-governmental organizations; women; small-scale farming; Tanzania

\section{Abstrak}

Perempuan Tanzania memainkan peran penting dalam pembangunan dan industrialisasi negara. Pertanian Tanzania dianggap sebagai tulang punggung negara, tetapi perempuan adalah kekuatan pendorong di belakang pertanian skala kecil. Studi ini bertujuan untuk mengidentifikasi jenis LSM yang mendukung perempuan, petani skala kecil, untuk menyelidiki pengaruh LSM, dan tantangan yang dihadapi petani skala kecil di Desa Tchenzema. Teori perkembangan model transisi dan pertumbuhan, dan teori patriarki digunakan dalam penelitian ini. Studi ini mengungkapkan bahwa transportasi yang buruk, penyakit tanaman dan serangga, kurangnya pestisida, fluktuasi harga, kekurangan energi, dan harga peralatan pertanian yang tinggi adalah beberapa masalah yang dihadapi oleh perempuan petani skala kecil di daerah Tchenzema. Studi ini menyimpulkan bahwa kurangnya kerjasama antara pemerintah Tanzania dan petani menyebabkan petani hanya mengandalkan LSM. Pemerintah dan lembaga swadaya masyarakat perlu mendukung perempuan petani kecil untuk mengatasi tantangan, dan meningkatkan output, sehingga sektor pertanian dapat mencapai tujuan nasional pertumbuhan ekonomi.

Kata Kunci: pertanian; organisasi non-pemerintah; perempuan; pertanian skala kecil; Tanzania

\section{Introduction}

Approximately two-thirds of the world's 3 billion rural inhabitants live in roughly 475 million small farm households on landholdings of less than 2 hectares. Many are impoverished, have little access to markets and services, and are food insecure. Their options are limited, yet they farm their land and 
feed a significant percentage of the world's population. Aside from farming, they engage in a variety of economic activities, many of which are in the informal sector, to supplement their meager earnings. The majority of the labor on these small farms is provided by family members. According to FAO, In China, approximately $98 \%$ of farmers work on farms that are less than 2 hectares in size. The nation accounts for about half of the world's small-scale farmers. Around $80 \%$ of farmers in India are smallscale farmers. Farms of less than 2 hectares account for approximately $90 \%$ of the total number of farms in Ethiopia and Egypt. In Mexico, smallholder farmers account for 50\% of all farmers, while in Brazil, smallholders account for $20 \%$ of all farmers.

Women still confront significant economic problems, according to Bellows et al. (2013) in their book "Rights to Food and Nutrition". Despite this accomplishment, women in underdeveloped nations have several obstacles when it comes to farming. Lack of land ownership was one of them. MARAG launched the Jameen Bachao Andolan (Movement to Protect Land) in 2006 in response to a government resolution on corporate farming. On May 17th, 2005, the Gujarat government issued a resolution stating that 4.6 million hectares of "wasteland" will be leased for 40 years to existing wealthy and capable farmers and corporate enterprises for agricultural development. This underlines the fact that over 1.9 million hectares of the 4.6 million hectares of so-called "wasteland" were cultivable land, implying the conversion of small-holder agricultural holdings into large-scale capitalist farms owned by companies and wealthy farmers (Bellows et al. 2013).

In the United Republic of Tanzania, agriculture employs around $75 \%$ of the people although production is among the lowest in Sub-Saharan Africa. The use of human labor to till the land, the restricted use of better seed and fertilizer, and low-yield indigenous animal breeds all contribute to poor production. Agriculture accounts for a quarter of the URT's gross national product and around 34\% of foreign exchange profits during the last ten years, with an annual growth rate of roughly 4.2 percent. This study on Tanzanian women small-scale farmers claims that farming is women's primary source of income and the path to their empowerment. As a result, the study investigates how NGOs assisted Tanzanian women small-scale farmers (Agunga et al. 2018).

Nevertheless, women are involved in the majority of agricultural operations, as well as household and child-care responsibilities, but they face several barriers that prevent them from taking advantage of agricultural training programs. It's also conceivable that women have less opportunity to gain agricultural knowledge and skills. As a result, there is an anticipation that more effort will be dedicated toward women than present training, which assumes that all farmers have the same needs. It appears that the existing approach assumes that all smallholder farmers have the same requirements and circumstances. Female-intensive agriculture refers to a sector in which women make up the majority of the workforce (54\%). Agriculture has a larger role in women's economic activities than it does in men's: Agriculture employs eighty-one percent of women and seventy-three percent of men. In rural areas, women make up about $98 \%$ of the population. Tanzania has a greater proportion of adult agricultural workers than the rest of the area, particularly among women: $81 \%$ of Tanzanian women work in agriculture, compared to $55 \%$ for the rest of Sub-Saharan Africa.Despite the significance of women in fighting food poverty, as shown in most Tanzanian research, and despite various initiatives and policies aimed at empowering women, household food insecurity remains an issue in Tanzania (Leavens et al. 2011).

Agriculture is the household's major source of revenue and supports virtually all of the household's activities. Most families eat what they cultivate, exchange items for other requirements, and make money by selling their crops or cattle. Smallholder households, despite the numerous uses of their agricultural produce, frequently fall short of their monthly financial demands. The majority of homes are at or below the poverty level, and many are in dire straits. They put in long hours, have lofty goals, and are proud of their achievements (Anderson et al. 2016).

Tanzania's small-scale agriculture system is classified as a least developed, low-income, food-deficit country, with over $80 \%$ of the population relying on subsistence agriculture for survival. Poverty is 
prevalent, with almost 58 percent of the population living on less than 1usd per day, according to current UN Food Program figures. Tanzania has recently begun to push medium and small-scale commercial farming more vigorously. Resources are being mobilized for irrigation development and mechanized farming. Land ownership, environmental management, and rural development programs will all be impacted by this decision. Given the size and importance of the agricultural sector in Tanzania's economic and social development endeavors, all agrarian and rural development plans will continue to be driven by this sector (Ministry of Finance of Economic Affairs 2010).

Agriculture is still dominated by small-scale farmers, with hand hoes accounting for around $70 \%$ of farming, ox-ploughs for $20 \%$, and tractors for $10 \%$. Despite this, the industry has been highlighted as a growth driver. Many crops, cattle, and forestry products may be grown in the varied climatic zones, which also offer enough water for irrigation and livestock, as well as a considerable amount of arable land. As a result of its involvement in assisting the rural poor and lowering malnutrition, agriculture has the potential to help many people escape poverty. Furthermore, rising food demand in neighboring nations offers agriculture with further chances to develop and boost exports to these countries ( Ministry of Finance of Economic Affairs 2010). This study aims to identify the types of NGO's that support women small-scale farmers, to investigate the effects of NGOs, and the challenges that small-scale farmers face in Tchenzema ward.

According to the National Development Vision (NDV) 2025 and the National Strategy for Growth and Poverty Reduction (NSGRP) 2005, agriculture is the foundation of the economy. The agricultural sector includes sub-sectors such as crops, livestock, forestry, and hunting. Smallholder farming dominates agriculture, with a large portion of it utilized for sustenance. It contributes significantly to total growth, exports, employment, and links with other sectors. It is home to around $80 \%$ of the population, who mostly rely on farming for a living. Between 1999 and 2006, the crop and livestock sub-sectors earned about $35 \%$ of foreign exchange gains. It supplied roughly 75 percent of total employment and 26.2 percent of GDP in 2006, according to Revised National Accounts Estimates for Tanzania Mainland, using 2001 as a base year. One of the pillars for achieving the NSGRP's medium-term poverty reduction targets was agricultural growth of at least $5 \%$ by 2003. Agriculture grew by 4.9 percent in 2001 and 2002, which was accomplished across the board. Agriculture contributed 26.2 and $25.8 \%$ of total GDP in 2005 and 2006, respectively. It increased at a pace of 4.3 percent in 2005 and then decreased to 3.8 percent in 2006. As a result, agriculture remains the principal source of income for the great majority of the population, and its performance has an impact on general improvements in living standards and economic growth (Ministry of Finance of Economic Affairs 2010).

Meanwhile, the goal of development theory has been to enhance living standards and quality of life for the vast majority of people, or, more recently, the poorest of the poor. To boost incomes directly and to expand the taxable capacity that underpins excellent government services, this usually necessitates economic development that outpaces population growth. The high-income nations are clearly urbanized, with substantial industrial and service sectors. Agriculture accounts for just $2 \%$ of their GDP, compared to $10 \%$ in middle-income nations and $41 \%$ in low-income ones. Economic Growth is fueled by increases in the amount and quality of a country's accessible elements of production, such as land, labor, capital, and entrepreneurship.

In contrast, if the quantity and quality of any of the production components decreases, economic decline may ensue. Improving land resources quantity and quality increases in the amount of agricultural land accessible will boost economic growth. The extent to which this occurs, however, is restricted by the amount of unused land that can be turned to agricultural land. Land is in short supply as a viable economic resource. There is a price to be paid for land. Wildlife no longer has a home on land that has been turned to agriculture. The law of decreasing returns may become significant due to the shortage of land in the face of rising population. According to the law, when more labor is done to a certain area of land, the labor productivity would decrease. The quality of the soil must be upgraded to prevent this loss of output (e.g., improved irrigation, fertilizers, pest control) (Ish-Shalom 2006). 
Agriculture employs a larger share of the work force in most low-income nations than it does of the production value. Many development economists in the 1950's and 1960's argued that a structural transformation leading to industrialization of their economies was required to transfer workers into higher-productivity sectors. Proposed a quick take-off stage, for which an increase in the productive investment rate to above $10 \%$ of national income was a required prerequisite. Due to a lack of private capacity in the 1960s, it was widely assumed that such investments would have to be undertaken by the government. As a result, marketing boards and export tariffs imposed enormous levies on (Szelenyi 2008).

Sylvia Walby's patriarchy theory the patriarchy premise explains why males, as the dominating figure in society, aim to oppress and control women. The most persistent and widespread ideology of today's women's movement is patriarchy. It takes many forms, but the underlying theories that male dominance or misogyny persists not only as a byproduct of capitalism but as something distinct from capitalism that has endured beyond capitalism are so widely accepted that dismissing the principle completely is met with complete and sincere surprise. Women's oppression and the form of the family have altered throughout time, and such notions ignore this. There is also a lack of understanding of how inequality varies by socioeconomic class. Instead, we're presented with the "eternal reality" that "patriarchy" is at the foundation of women's subjugation in some way.

This is explained by pointing to the presence of gender inequality in cultures with abuse, in farming societies women are the main workers but men are the one selling the products and keep the money, or dictate the usage of the money. Which the patriarchy theory supports the widely held belief within the women's movement that there must be a division of struggles: socialism and the workers' movement fight capitalism, while the women's movement fights patriarchy. The justification for dividing the efforts now is that each gender will have its own societal development in the future. Many advocates of the patriarchy hypothesis would disagree with this argument.

\section{Research Methods}

This study used a mixed method approach, which included both qualitative and quantitative data. A cross sectional research design was also utilized in the study, which is a sort of observational study that involves analyzing data collected from a population at a certain point in time. It aids in the collection of cross-sectional data from respondents by posing questions to them via surveys and interviews. According to Kothari, research technique refers to the structuring of conditions for collecting and assessing data in a way that aims to combine relevance to the study objective with procedural efficiency (Kothari 2004). In this particular study, primary data were all inclusive and collected form the field. There are 50 informants, small-scale farmers and important respondents such as (MEO) Mtaa Executive Officer, WEO (Ward Executive Officer), VEO (Village Executive Officer), Agriculture officer, and NGO officials were interviewed in Mvomero District. Secondary data, according to Adam \& Kamuzora (2008), refers to data that has been released as well as data acquired in the past by other parties. Data will be gathered from a variety of written materials held by the relevant office, including published reports pertaining to the study's topic, files, and other literature.

Random sampling procedure were employed in the study to choose respondents, while non-random selection approaches were used for VEO, WEO, MEO, and other village members of various village committees. Small-scale farmers were chosen at random. All of the above respondents are directly or indirectly involved in cash crop production and are affected by weak market conditions, as well as those who are accountable for increasing output, which is what the research issue was about. To eliminate bias, a sampling approach such as simple random sampling was employed to obtain responses.

Tchenzema ward is part of Mgeta Division, which is part of the Mvomero District, and is located on the western slopes of the Uluguru Mountains. The ward's three settlements are Langali, Nyandira, and 
Tchenzema. The villages are located along the road to Mzumbe. Rainfall ranges from 1,000 to 2,000 $\mathrm{mm}$ on average, with higher elevations seeing larger quantities and more constant seasons. Tchenzema has a population of 2,400 people, while Langali has a population of 2,200. Nyandira has a population of 2,500, and Langali has a population of 2,200. Maize is the most common crop cultivated in this area, and it is farmed by the majority of families. Even yet, the amount produced is rarely enough to fulfill a year's worth of food demand.

On the other hand, data were collected using a variety of methods, including interviews in which respondents were asked direct questions or face to face questions in the study area in order to obtain a more detailed picture of the situation. Physical observation was applied, and also the questionnaires were employed and the respondents were asked a series of questions in order to gather information on the research area. Respondents were handed questionnaires and were required to read and comprehend the questions before writing down their answers in the area provided on the questionnaire. Also, a Focus Group Conversation was used to discuss the subject. In this way, participants who were less than ten in number were permitted to share their thoughts, while the researcher acted as an observer of the discussion and took notes on the study's important findings.

Data analysis using textual analysis and quantitaive table analysis, which entails deciphering and analyzing the language used, noting symbols, and taking photographs to learn how respondents react to the studied phenomenon. This method provides information on written, visual, or spoken messages that must be deciphered. Textual analysis is used to interpret the available data and information (Finkelstein 2005). This helps study in categorizing and reducing the number of concepts to work on, as well as building the "big picture" of findings relevant to understanding social phenomena. (Finkelstein 2005).

\section{Results and Discussion}

According to the study results, inadequate transportation, crop diseases and insects, a shortage of pesticides, price fluctuations, a lack of energy, and exorbitant agricultural equipment prices are some of the difficulties women small-scale farmers confront in Tchenzema ward. This section includes a thorough explanation of the findings, discussions of significant findings, and the methodologies used in this study, as well as a rationale for their selection. First, a description of the study's informants is provided, as well as an explanation of the statistical methodologies used in the data analysis. The analysis of the data gathered in the verbal-guise phase of the research continues in this section. The results of the major impacts are then shown, as well as the results of the data analysis conducted in the dialect recognition portion of the study instrument. Some table below, gave an extremely broad remarks on the findings which were recorded.

Table 1.

Types of NGOs in Tchenzema ward

\begin{tabular}{lcc}
\hline NGOS in Tchenzema ward & $\begin{array}{c}\text { Frequency (known } \\
\text { to the public) }\end{array}$ & Percentage \\
\hline MVIWATA & 23 & $46 \%$ \\
KIMU & 21 & $42 \%$ \\
UMADEP & 4 & $8 \%$ \\
IFAD & 2 & $4 \%$ \\
Total & $\mathbf{5 0}$ & $\mathbf{1 0 0}$ \\
\hline
\end{tabular}

According to the data in Table 1, MVIWATA is the type of NGO that supports women small-scale farmers in Tchenzema ward (46\%) and KIMU is the type of NGO that supports women small-scale farmers in Tchenzema ward (42\%) and UMADEP is the type of NGO that supports women small- 
scale farmers in Tchenzema ward (8\%) and IFAD is the type of NGO that supports women small-scale farmers in Tchenzema ward (4\%). This research reveals that small-scale farmer in Tchenzema Ward value MVIWATA's contributions more than other NGOs, with one of its major contributions being the establishment of Nyandira's big market.

In the development debate and development cooperation, non-governmental organizations (NGOs) have played a critical role. They are intended to campaign for broad public goods like as human rights and democracy as civil society groups, and as service providers for the poor, they are expected to function more effectively and efficiently than the state. The literature, too, is divided on their importance to agricultural research and development. Local NGOs are widely recognized by governments, international institutions, and development agencies as being highly motivated in their work by solidarity, having direct contact with the local population, and thus enjoying a better understanding of local people's circumstances and needs (Jones \& Sanyang 2007).

This statement supports the NGOs in Tchenzema ward, which are also attempting to establish direct contact with the local community in order to assess local people's conditions and needs, allowing them to better reach the poor and aid them, as some NGOs are doing in farming operations. Furthermore, this evaluation validated local NGOs as key actors in the agricultural sector; throughout the study, the study confirmed that NGOS play a significant role for small-scale farmers in Tchenzema by enabling them to conduct sustainable agriculture and therefore escape extreme poverty. This potrays a clear picture that the non-governmental organizations (NGOs) have played an important role in the development debate and in development cooperation, there for same applied to the roles played by NGOs in Tchenzema conclude that it is true that there are NGOs which devote their resources to assist women small-scale farmers in Tchenzema ward. Recently in Tanzania a new UN Women and UNFPA-led joint program targeting vulnerable small-holder farmers in Tanzania's Shinyanga and Singida areas has begun in September 2020. It is expected to increase their earnings, allowing them to be more economically resilient and have more control over their lives at home and in their communities.

\section{Factors influencing NGOs to support women small-scale farmers in Tchenzema ward}

The researcher also attempted to uncover the variables that drive non-governmental organizations (NGOs) to force assistance on small-scale farmers by examining the criteria and factors that they use to impose their support in a certain location. The reasons driving NGOs to help small-scale farmers in Tchenzema ward are listed in the Table 2.

Table 2.

Factors influencing NGOs support in Tchenzema ward

\begin{tabular}{lcc}
\hline \multicolumn{1}{c}{ Factors } & Frequency & Percentage \\
\hline Availability of varieties of crop productions & 26 & $52 \%$ \\
Fertile soil & 18 & $36 \%$ \\
Climatic condition & 6 & $12 \%$ \\
Total & $\mathbf{5 0}$ & $\mathbf{1 0 0}$ \\
\hline
\end{tabular}

Source: Primary data

Table 2 shows that $(52 \%)$ of respondents cited the availability of crop varieties as one factor among others attracting NGOs to lend a helping hand to women small-scale farmers in Tchenzema ward, (36\%) of respondents cited fertile soil as a reason for NGOs to assist farmers in Tchenzema ward, and (12\%) of respondents cited the availability of water as a reason for NGOs to assist farmers in Tchenzema ward. Something noteworthy here is that NGOs choose to support women small-scale farmers in a specific location based on its potentiality, such as having good climatic conditions and fertile soil, which can lead to increased food crop production. The reason for this is that NGOs select areas with high production but fail to sell out their productions or develop from where they, not the place, are located. 
According to the findings of Amos (2012) research on the socio-economic factors influencing conservation and development trade-offs on the Uluguru mountains, tree planting, terracing, agroforestry, agriculture, schools, and dispensaries were the major conservation and development trade-offs present in the study area. In addition, the study found that land size and education level had a substantial impact on conservation and development trade-offs in the Uluguru Mountains. It has been directly revealed that in Tchenzema ward, the size of the land and the level of education of the civilians lead to NGOs' support; because they have a productive and fertile land, individuals are not well educated in the application of modern farming techniques; it has also been revealed that the availability of various types of productions is another factor. The primary causes that motivate NGOs to impose their assistance to women smallscale farmers in the region are to make the area sustainable in producing food crops as it is a prospective area that delivers its goods up to Dar-es-Salaam city.

\section{Impacts of NGOs to women small-scale farmers in Tchenzema ward}

This study was also interested to find out the impact of NGOs in helping women small-scale farmers in Tchenzema ward, views of respondents about the impacts of NGOs presented in Table 3.

Table 3.

Impacts of NGOs in Tchenzema ward

\begin{tabular}{lcc}
\hline \multicolumn{1}{c}{ Impacts } & Frequency & Percentage \\
\hline Building of the market (Nyandira) & 19 & $38 \%$ \\
Education on modern agriculture & 12 & $24 \%$ \\
Obtaining better production & 8 & $16 \%$ \\
Increase of production & 6 & $12 \%$ \\
Selling products for better prices & 5 & $10 \%$ \\
Total & $\mathbf{5 0}$ & $\mathbf{1 0 0}$ \\
\hline \multicolumn{2}{c}{ Source: Primary data }
\end{tabular}

From Table 3, the study shows that the contribution of NGOs to women small-scale farmers of Tchenzema ward are recognizable by the farmers, according to the findings, $(38 \%)$ of respondents cite the construction of Nyandira market as one of MVIWATA's greatest contributions to them, $(24 \%)$ of respondents cite education as one of its impacts, and (16\%) of respondents cite the a factor of NGOs plays a critical roles on supporting farmers. According to the MVIWATA annual report, 2252 farmers (1112 women and 1140 men) were taught in crop husbandry, particularly maize and rice, through a farmer to farmer method in which 293 farmers (128 women and 165 men) trained other farmers. Farmers who engaged in this project boosted maize output from an average of 3.0 tons per hectare to around 8.0 tons per hectare, and rice production from 3.9 tons per hectare to 9.0 tons per hectare (MVIWATA 2013).

Tanzanian women small-scale farmers require a wide range of agricultural inputs or resources, such as technology (modern farming implements), better seed, and chemical fertilizers, to boost production. They also require cash or loans, as well as land rights. When the findings of the study are compared to the elements emphasized by respondents from the study region as the impacts of NGOs support to women small-scale farmers in Tchenzema, the annual report of MVIWATA 2013 reveals that NGOs contribute to the growth of agricultural operations. Factors such as increased output demonstrate that non-governmental organizations (NGOs) have effectively forced their aid on the farmers of Tchenzema ward (Isaya et al. 2018).

NGOs play a vital role in assisting women small-scale farmers in Tanzania. However, the issue of price fluctuation is difficult to handle but must be addressed. Huka et al. (2014) recommends a variety of strategies for the government and other stakeholders to reduce agricultural commodity price volatility 
and enhance market management and control. Buffer stocks, increased investment in agriculture sectors, particularly in research and development and irrigation infrastructure, and improved trade policies, including agricultural subsidies, are just a few examples. The FAO, on the other hand, should step up its efforts to acquire and disseminate information in order to promote market transparency. During crises, financing mechanisms like the IMF should be made more flexible and beneficial for developing nations. The regulatory frameworks of commodity markets should also be revised in order to decrease speculative behavior and therefore restrict it (Huka et al. 2014).

\section{Challenges facing women small-scale farmers in Tchenzema ward}

The researcher also highlighted the problems faced by women small-scale farmers in Tchenzema ward, with 50 respondents providing their perspectives on the major obstacles that impede their agricultural activities, as shown in Table 4.

Table 4.

Challenges facing women small-scale farmers in Tchenzema ward

\begin{tabular}{lcc}
\hline \multicolumn{1}{c}{ Challenges } & Frequency & Percentage \\
\hline Poor transportation (road) & 23 & $46 \%$ \\
Crop diseases and insects due to lack of pesticides & 11 & $22 \%$ \\
Price fluctuation & 8 & $16 \%$ \\
Lack of electricity & 6 & $12 \%$ \\
Lack and high price of agricultural equipment's & 2 & $4 \%$ \\
Total & $\mathbf{5 0}$ & $\mathbf{1 0 0}$ \\
\hline \multicolumn{2}{c}{ Source: Primary data }
\end{tabular}

According to Table 4, the issue of transportation is the leading challenge for farmers (46\%), while crop diseases and insects due to a lack of pesticides are the second most common challenge for farmers $(22 \%)$, and price fluctuation is the third most common challenge for women small-scale farmers (16\%). On the other side, 12 percent of respondents cited a lack of power in their village as a barrier, while the remaining 4 percent cited a lack of agriculture equipment and expensive prices as a difficulty for women smallscale farmers. The ASDP Resettlement Policy Framework document (2005) identifies key roadblocks to Tanzania's agricultural growth goals, such as the transition from subsistence to commercial agriculture and the expansion of existing commercial enterprises, as well as high transaction costs due to poor infrastructure, particularly rural roads, and the overall policy and regulatory environment. The ASDP Resettlement Policy Framework document (2005) also addressed issues such as poor infrastructure, the overall policy and regulatory environment governing market transactions (including tax regimes and licensing requirements and costs), and other issues that women small-scale farmers face (Cooksey 2013).

The research highlights the issue of mobility, such as road, the most significant challenge for farmers (representing 46\% of the issues), ASDP Resettlement Policy Framework identified the poor state or absence of infrastructure, particularly rural roads, as a problem demonstrates that transportation is a major barrier for women small-scale farmers, and the problem is genuine, as previous researches have discovered Farmers should be mobilized, educated, and empowered to establish their own Micro Enterprises (MEs), Micro-Finance Institutions (MFIs), and Savings and Credit Cooperative Societies (SACCOs), which will assist them in obtaining capital and funds in the form of credits for the development and expansion of women's small-scale farming production (Stuetz et al. 2019).

Farmers confront serious hurdles, according to Misaki et al. (2016) results, factors such as shortage of farming inputs, transportation infrastructure, access to health centers, access to finance, and interest rates imposed by banks. Furthermore, the data show that the vast majority of farmer households $(90 \%)$ lack 
access to electricity. Small-scale farmers confront several obstacles, including insufficient agricultural equipment, poor transportation infrastructure, limited access to health care, and no access to energy, according to previous studies (Misaki et al. 2016).

However, in order to enhance production, Tanzanian women require a range of agricultural inputs or resources, including technology, finance, better seed, and chemical fertilizers, among other things. By maintaining and increasing soil organic matter and biological nitrogen fixation from nitrogen-fixing tree species, improved technology has the ability to improve soil fertility (Matata et al. 2010). Technology is vital as if it's conveniently available at low cost, requiring less time to prepare, bridging food shortages during dry seasons, and providing money to women without men's involvement as they met their need for household food security and income (Muhanji et al. 2011). The factors of women's empowerment are studied using ordinal logit analysis. Age of the household head, education level, housing quality, monthly income, group participation, and distance from the next large town were all important factors for female-headed households (Achandi et al. 2019).

\section{Conclusion}

The study's main goal was to investigate a variety of problems surrounding the role of NGOs in supporting Tanzanian women small-scale farmers. However, the study concluded that in order to address these challenges, women small-scale farmers, the government, and non-governmental organizations (NGOs) should collaborate. Women small-scale farmers should create their own unions and associations to focus on addressing their own difficulties rather of relying on NGOs, which are not guaranteed to be around forever to service their needs, according to the study's findings. The issue of a shortage of cash to operate farming operations and purchase agricultural equipment will be resolved as the union/group will play a role in assisting members by building a foundation of financing members such as loans for their activities. On the other hand, women small-scale farmers need a viable market for their agricultural products in order to have a long-term and steady income. In Tchenzema ward farmers lack support from small industries. It shows that, in collaborations with small local processing plants must be established as part of strengthening women's small-scale farming. Farmers are motivated to protect habitat and resources near to the Kilombero Nature Reserve and key habitat corridors because they have access to suitable market and greater earnings.

Based on the study's results, the following recommendations should be followed by farmers, the government, NGOs, and other development partners should unite in order to reduce and eliminate the problems that women small-scale farmers face in Tchenzema ward. As agriculture is the backbone of the economy where by about $75 \%$ of the population of the United Republic of Tanzania is employed in agricultural activities. The Government should initiate strategies aiming to help women small-scale farmers to overcome their challenges. Issues like the use of technology is highly advised. Through farmer-to-farmer learning and government extension services, technologies that create high-value crops and fulfill various requirements of farmers are easily implemented.

Tanzania must, however, invest in women empowerment through financial resources as well as research into adaption strategies that may be used to cope with climate change. Indigenous peoples have been recognized as important knowledge holders on climate change and crucial actors in crafting policies to cope with and adapt to its effects, according. As a result, employing local people is thought to lead to the creation of cost-effective, participative, and long-term mitigation and adaption solutions. The government's participation in supporting the industry is critical for effective transition of women smallscale farmers from subsistence to commercial farming. The studies show that, workload, resource ownership, and restricted inputs to productive decision making are major areas leading to women's disempowerment, while males reported both workload and restricted input to productive decision making. 


\section{References}

Achandi EL, Kidane A, Hepelwa A, \& Mujawamariya G (2019) Women's empowerment: The case of smallholder rice farmers in Kilombero District, Tanzania. Agrekon 58 (3):324-339. https://doi.or g/10.1080/03031853.2019.1587484.

Adam J \& Kamuzora F (2008) Research for Business and Social Studies. Morogoro: Mzumbe Book.

Agunga R, Sanga CA, \& Isaya E (2018) Empowering women farmers in Tanzania through communication for development. World Journal of Social Science 5 (2):1-8. https://doi.org/10.5430/wjss.v5n2p8.

Amos M (2012) Socio-economic factors influencing conservation and development trade-offs on Uluguru mountains, Tanzania. Dissertation, Sokoine University of Agriculture, Morogoro.

Anderson J, Learch CE, \& Gardner ST (2016) National survey and segmentation of smallholder households in Bangladesh: Understanding their demand for financial, agricultural and digital solutions. CGAP Working Paper, April 101.

Bellows A, Callenius C, Campeau C, Cedeno MA, \& Wolpod-Bosien M (2013) Right to Food and Nutrition Watch: Alternatives and Resistance to Policies that Generate Hunger. Berlin: Wilma Strothenke.

Cooksey B (2013) The Comprehensive Africa Agriculture Development Programme (CAADP) and agricultural policies in Tanzania: Going with or against the grain? FAC Political Economy of Agricultural Policy in Africa (PEAPA), 1-46.

Finkelstein DM (2005) A beginner's guide. Technometrics 47 (4):522-522.

Huka H, Ruoja C, \& Mchopa A (2014) Price fluctuation of agricultural products and its impact on small scale farmers development: Case analysis from Kilimanjaro Tanzania. European Journal of Business and Management 6 (36):155-161.

Isaya EL, Agunga R, \& Sanga CA (2018). Sources of agricultural information for women farmers in Tanzania. Information Development 34 (1):77-89. https://doi.org/10.1177/0266666916675016.

Ish-Shalom P (2006) Theory gets real, and the case for a normative ethic: Rostow, modernization theory, and the alliance for progress. International Studies Quarterly 50 (2):287-311. doi:10.1111/j.14682478.2006.00403.x.

Jones MP \& Sanyang S (2007) Promotion inclusion of civil society organizations (CSOs) in African Agricultural Research and Development. Brighton: University of Sussex, Institute of Development Studies.

Khan S (2015) Sustainable local economic development (LED) and rural land reform challenges and prospects in post-apartheid South Africa-A policy perspective. Journal of Economics 6 (1):8-17.

Kothari CR (2004) Research Methodology: Methods and Techniques New Delhi: India.

Leavens, Kennedy M, \& Anderson L (2011) Gender and Agriculture in Tanzania. Gates Open Research $3: 1-14$.

Massay EM (2021) A review on the prevailing gaps in women's sexual and reproductive health rights in Tanzania's National Health Policy 2017. Jurnal Sosiologi Dialektika 16 (1):1-11.

Matata PZ, Ajay OC, Oduol PA, \& Agumya A (2010) Socio-economic factors influencing adoption of improved fallow practices among smallholder farmers in western Tanzania. African Journal of Agricultural Research 5 (9):818-823. https://doi.org/10.5897/AJAR.9000639.

Ministry of Finance of Economic Affairs (2010) National Strategy for Growth and Reduction of Poverty (NSGRP II). Tanzania: United Republic of Tanzania.

Misaki E, Apiola M, \& Gaiani S (2016) Technology for small scale farmers in Tanzania: A design science research approach. The Electronic Journal of Information Systems in Developing Countries 74 (1):1-15.

Muhanji G, Roothaert RL, Webo C, \& Stanley M (2011) African indigenous vegetable enterprises and market access for small-scale farmers in East Africa. International Journal of Agricultural Sustainability 9 (1):194-202. https://doi.org/10.3763/ijas.2010.0561.

MVIWATA (2013) Annual Report 2013. Morogoro: MVIWATA.

Pretty J, Toulmin C, \& Williams S (2011) Sustainable intensification in African agriculture. International Journal of Agricultural Sustainability 9 (1):5-24. https://doi.org/10.3763/ijas.2010.0583. 
Stuetz W, Gowele V, Kinabo J, Bundala N, Mbwana H, Rybak C, Eleraky L, Lambert C, \& Biesalski HK (2019) Consumption of dark green leafy vegetables predicts vitamin a and iron intake and status among female small-scale farmers in Tanzania. Nutrients 11 (5):1-18. https://doi.org/10.3390/ nu11051025.

Szelenyi I (2008) A theory of transitions. Modern China 34 (1):165-175.

Tiernan M \& Nelson C (2013) Women in Tanzania Agribusiness: Case Studies of Women in Tanzanian Agribusiness. Tanzania: The Women in Public Service Project. 